\title{
Fibrin sheath following pleurodesis
}

\author{
Hiromichi Yamane, Nobuaki Ochi, Tomoko Yamagishi, Nagio Takigawa
}

General Internal Medicine 4, Kawasaki Medical School, Okayama, Okayama, Japan

\section{Correspondence to}

Dr Hiromichi Yamane, hiromichi.ya@gmail.com

\section{DESCRIPTION}

A 63-year-old man was admitted to our hospital with drug-induced interstitial pneumonia. He was treated with corticosteroid and showed a partial decrease in the interstitial shadow. However, secondary pneumothorax was detected on day 28 of the treatment (figure 1A), thoracic drainage catheter was inserted. Although pleurodesis using autologous blood was performed twice, air leakage could not be improved. Therefore, pleurodesis using a 50\% glucose solution was performed again, which resolved the pneumothorax with spontaneous tube extraction. Chest CT after spontaneous tube extraction showed an intrathoracic passage route of drainage tube with a fibrin sheath (figure 1B-D). A fibrin sheath is often described as a complication of central venous catheterisation and associated with venous occlusion. ${ }^{1}$ In the present case, we speculate that pleurodesis using autologous blood could have been the cause of the intrathoracic fibrin sheath.
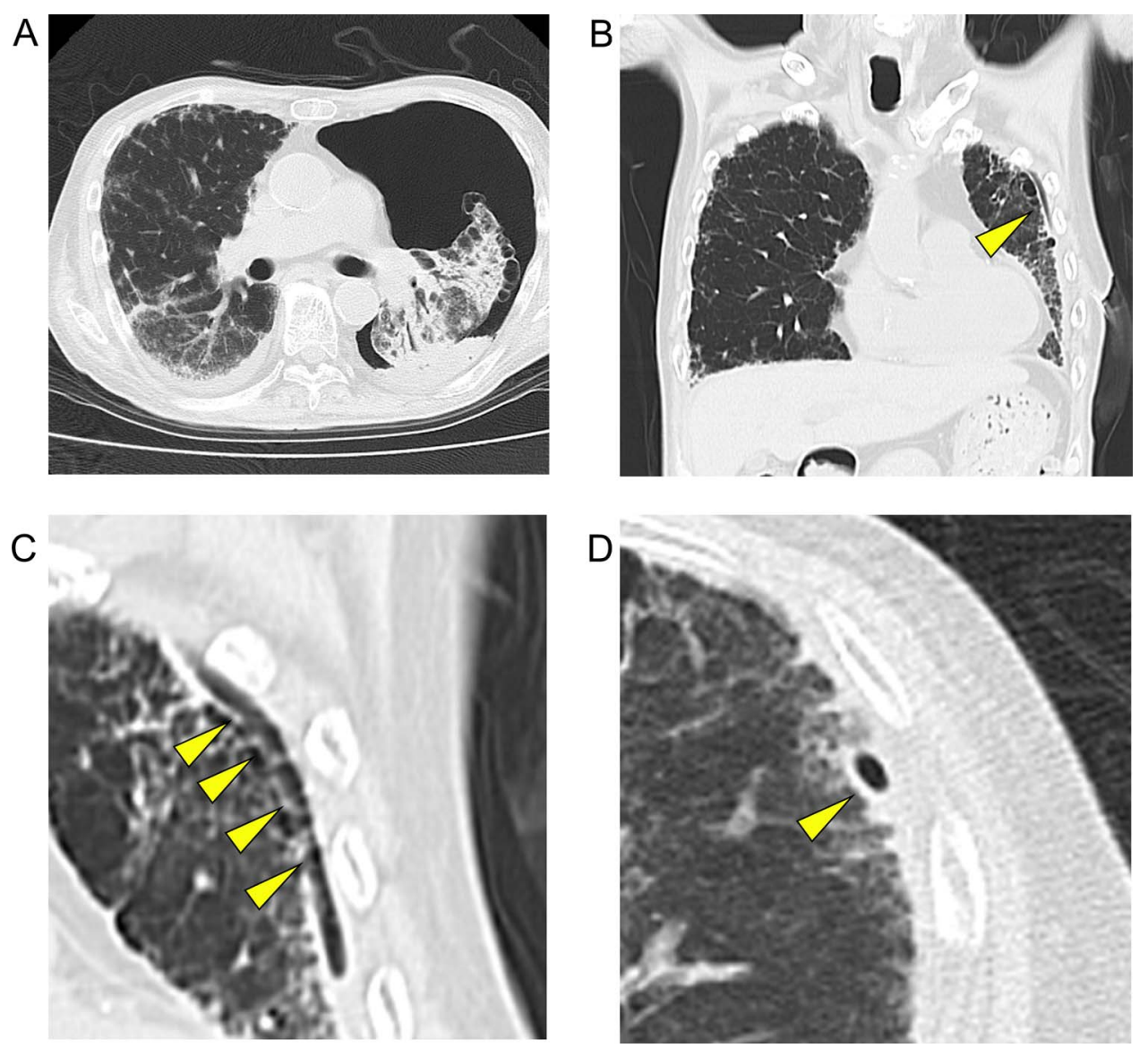

Figure 1 (A) Chest $\mathrm{CT}$ revealing pneumothorax in the left thorax, interstitial pneumonia in the right lower lobe and multiple bulla in the left upper lobe. (B-D) Chest CT after spontaneous tube extraction revealing an intrathoracic passage route of drainage tube with a fibrin sheath (arrow head). 
Competing interests None.

Patient consent Obtained.

Provenance and peer review Not commissioned; externally peer reviewed.

\section{REFERENCE}

1 Krausz DJ, Fisher JS, Rosen G, et al. Retained fibrin sheaths: chest computed tomography findings and clinical associations. J Thorac Imaging 2013. [Epub ahead of print].

Copyright 2014 BMJ Publishing Group. All rights reserved. For permission to reuse any of this content visit

http://group.bmj.com/group/rights-licensing/permissions.

BMJ Case Report Fellows may re-use this article for personal use and teaching without any further permission.

Become a Fellow of BMJ Case Reports today and you can:

- Submit as many cases as you like

- Enjoy fast sympathetic peer review and rapid publication of accepted articles

- Access all the published articles

- Re-use any of the published material for personal use and teaching without further permission

For information on Institutional Fellowships contact consortiasales@bmjgroup.com

Visit casereports.bmj.com for more articles like this and to become a Fellow 